\title{
ANTONIO CANDIDO, TAMBÉM FILÓLOGO?
}

\author{
Lucas de Lacerda Zaparolli de Agustini* \\ Marcelo Módolo**
}

CANDIDO, Antonio. Noções de análise histórico-literária. São Paulo: Associação Editorial Humanitas, 2005.

Publicado pela Associação Editorial Humanitas em janeiro de 2005, o livro Noções de análise histórico-literária comporta as aulas ministradas pelo insigne intelectual Antonio Candido de Mello e Souza para os alunos do primeiro ano do curso de Letras da Faculdade de Assis, em 1959.

A matéria era chamada Introdução aos estudos literários. O programa do curso - então proposto pelo professor Antonio Candido - almejava dar maior visibilidade à crítica textual, desse modo sendo dividido em duas partes: a que coube a ele resulta nas lições que compõem esse compêndio; a outra, a análise estética do texto propriamente dita, foi desenvolvida pelo falecido professor Naief Sáfady.

Após uma indispensável Explicação na qual o professor tece a mea culpa de serem essas aulas obsoletas na maior parte, havendo já passado meio século, e que não sem muita relutância e meio constrangido autorizou a reprodução das mesmas, depara-se com a configuração do livro cindida em três partes: A Obra; $O$ Autor e O Tempo. Absolutamente didático, esse livro, que mantém o formato da antiga apostila, abrange apenas três quartas partes de A Obra: O Texto Manuscrito; O Texto Impresso; A Autoria; excluindo a questão do Destino da Obra.

\footnotetext{
* Graduação, USP

${ }^{* *}$ DLCV, USP.
} 
Tal como se percebe nos três tópicos abordados, tal como explicitado na Introdução ao curso, o estudo versa acerca do caráter físico, material, e histórico da obra literária que, conquanto aspecto acessório, como indica o próprio professor, é sem dúvida o corpo do texto, indissociável, portanto, de sua alma, ou seja, seu essencial, "o alcance artístico e humano". Poderia dizer-se, ainda seguindo as palavras do autor, que este é um curso de Filologia, fosse o caso de depreender deste termo somente a ideia de "estudo dos elementos técnicos e culturais que permitem esclarecer um texto literário", o que, porém, não sucede.

Esse opúsculo, em se notando suas breves 114 páginas, fornece concisa, mas meticulosamente, todo o saber básico para um neófito nas veredas da crítica textual; com análise rigorosa e perspicácia, relativiza os próprios exemplos que suscita, todos embasados a fundo na teoria de autores imprescindíveis, citados em duas bibliografias que constam nos interstícios das tarefas - ou seja, das partes acima indicadas.

A Primeira Tarefa, o Texto Manuscrito, subdivide-se em $O$ Manuscrito $e$ suas Modalidades, que tratará das variações de manuscritos, dos autógrafos, apógrafos, da natureza dos manuscritos, do seu conjunto, ou Códice etc. O segundo momento dentro da Primeira Tarefa tem por tema os Problemas de Leitura da grafia manual (cursiva ou bastão) e da escrita advinda da tipografia. Esse subcapítulo trata ainda da necessidade de conhecimentos paleográficos a fim de se evitar erros gravíssimos, oriundos de leitura equivocada. Ainda dentro desta parte, discorrerá a respeito das variantes vocabulares, sintáticas, frasais, que um autor utiliza em detrimento de outra forma, das versões que um apanhado de textos com variantes próprias acarretará, das lições, isto é, a versão com as variantes preferidas etc. $\mathrm{O}$ terceiro tema abordado é inerente à Localização do Manuscrito, quer no aspecto espacial, desde a busca em catálogos de anais de bibliotecas até algum encontro inesperado, à mercê da sorte, em baús privados repletos de documentos antigos; quer no aspecto temporal, a determinação da data em que tal ou qual manuscrito fora redigido e suas implicações para o conhecimento da própria biografia do autor ou seu percurso literário, além da "estrutura dos períodos".

A Segunda Tarefa, O Texto Impresso, subdivide-se em "Edição”: sua necessidade e critérios, na qual se confirmará a extrema importância de uma edição fidedigna para o trabalho do intelectual; trata também de três tipos de edições: facsimilar, diplomática e crítica, detendo-se vagarosamente nesta última por ser a "mais perto possível da vontade do autor". 
Cindindo a questão da edição crítica em dois tópicos, tem-se o segundo momento, Edição Crítica: Fixação do Texto, que fala, após um diminuto percurso histórico, a respeito do "preparo sistemático" iniciado pelo teórico alemão Karl Lachmann, detalhando com minúcias todo o procedimento de collatio, recensio, emendatio etc, e passeando pela enumeração valorativa dos tipos de textos que se podem apresentar ao crítico textual, cuja função será descobrir entre os mesmos qual é a edição príncipe, qual a edição definitiva, e quais variantes, depois de árdua comparação entre as obras, serão adotadas na edição crítica.

Posteriormente se encontra a terceira subdivisão, Edição Crítica: apresentação do texto, onde Antonio Candido arguirá que aí existem dois tipos não excludentes: um decorrente da crítica textual, que forma o Aparato Crítico; outro que serve de complemento apenas, contendo introduções, listas de edições, glossários etc. Ao fim desta Segunda Tarefa, topa-se com o tópico do Manuseio da Edição, momento em que os estudantes "devem se familiarizar com Edições Críticas" e são analisadas 12 delas em conjunto com os alunos, numa espécie de crescente qualitativo: partindo da edição d'Os Lusíadas elaborada por José Maria Rodrigues e chegando ao monumental Cantar de Mio Cid, em dois volumes, com tudo que é de direito a uma impecável edição crítica, realizada por Menéndez Pidal.

A Terceira e última Tarefa do opúsculo trabalha, por sua vez, o assunto da Autoria. Subdividido em Conceito e configuração da autoria e Determinação da autoria, observa-se bem Antonio Candido pondo em prática longo conhecimento, abrangendo historicamente assuntos preciosos, espécies de burburinhos literários, perpassando a legislação tocante aos Direitos Autorais, detendo-se nos modos de identificação, pseudônimo, anagrama do nome, criptônimo, heterônimo, os motivos que levam o autor a ocultar-se, a singularidade e pluralidade da autoria; finalmente discorrendo sobre a determinação da autoria, a autoria ignorada, os tipos de autorias duvidosas, os motivos influenciadores da elaboração de Fraudes Literárias, terminando por analisar os casos mais conhecidos de fraude, como os Cantos de Ossian e as Poesias de Clotilde de Surville, os processos do descobrimento dessas fraudes etc.

Há ainda um trecho intitulado Critérios de Atribuição e Autenticidade, no qual são expostas "as provas a que se deve recorrer na tentativa de resolver problemas de autenticidade e atribuição", a saber, a análise dos materiais - papel, tinta, tipo de composição tipográfica; a análise de aspectos externos - testemunhos do autor, dados históricos e biográficos; e aspectos internos - o estilo, as provas do texto etc. 
AGUSTINI, L. L. Z; Módolo, M. Antonio Candido, também filólogo?

Como se vai notando, em muito breve espaço, didática, precisa e meticulosamente, embora aqui e ali com relativa obsolescência, Antonio Candido compartilha sua vasta erudição através de mais esta obra, fazendo, dos seus leitores, seus alunos, fazendo-se, como é costumeiro, mestre. 